\title{
Heat effected zone in unburned, antimony trioxide containing plasticised PVC
}

\author{
ALI I. AL-MOSAWI - University of Miskolc, Hungary = qkoali76@uni-miskolc.hu \\ KÁLMÁN MAROSSY - University of Miskolc, Hungary - polkal01@uni-miskolc.hu \\ Érkezett: 2018. 01. 17. - Received: 17. 01. 2018. - https://doi.org/10.14382/epitoanyag-jsbcm.2018.16
}

\section{Abstract}

What are the structural changes in the PVC layer located directly under the flame zone which is exposed to high temperatures without burning? We will try to explain in this article what actually happens in this layer, which we called heat affected zone. The layers were tested both with and without antimony trioxide (ATO or $\mathrm{Sb}_{2} \mathrm{O}_{3}$ ) flame retardant additive. Results obtained from Scanning electron microscopy (SEM) for the heat affected zone of the samples after Limited oxygen index (L.O.I.) test and compared with the samples before this test showed that there was a significant decrease in the chlorine content in the PVC structure accompanied by a significant increase in the carbon content. We suppose that this early dehydrochlorination improves the efficiency of $\mathrm{Sb}_{2} \mathrm{O}_{3}$.

Keywords: Plasticised PVC, HAZ, L.O.I., SEM, EDS

\section{Introduction}

The process of flame retardancy doesn't relate to the material's melting temperature itself, but depending only on the metaphase transformations that grow inside the material, as well as depends on compounds consisting after exposure retardant material to high temperatures. For instance, ceramic materials make a full thermal insulation due to the poor thermal conductivity but not necessarily resist flame, even if the high degrees of melting. The fire-inhibiting materials are on the contrary, they are in degrees of heat is one of the low-lying conductive materials, but at high flame is a good heat insulators in addition to immunity to flame spread [1]. Antimony trioxide is not considered a flame retardant when it is added to low-flame-resistant materials, but it is used to increase the flame retardant effect of halogen flame retardants if added to different proportions and as needed to improve its flame resistance performance [2-7]. When the polymer contains halogen flame retardants with antimony trioxide is exposed to flame, the antimony trioxide starts by interacting with the chlorine from the polymer, and chemical compounds such as $\mathrm{SbCl}_{3} \mathrm{SbOCl}$ will be formed which neutralize the free radicals, kill the flame and prevent its spread. This reaction mechanism is described in the equations as follows [8-12]:

$$
\begin{aligned}
& \mathrm{RCH}_{2}-\mathrm{CH}_{2} \mathrm{Cl} \rightarrow \mathrm{R}-\mathrm{CH}=\mathrm{CH}_{2}+\mathrm{HCl} \\
& 2 \mathrm{HCl}+\mathrm{Sb}_{2} \mathrm{O}_{3} \rightarrow 2 \mathrm{SbOCl}+\mathrm{H}_{2} \mathrm{O} \\
& 5 \mathrm{SbOCl}(s) \rightarrow \mathrm{Sb}_{4} \mathrm{O}_{5} \mathrm{Cl}_{2}(s)+\mathrm{SbCl}_{3}(g) \\
& 4 \mathrm{Sb}_{4} \mathrm{O}_{5} \mathrm{Cl}_{2}(\mathrm{~s}) \rightarrow 5 \mathrm{Sb}_{3} \mathrm{O}_{4} \mathrm{Cl}(\mathrm{s})+\mathrm{SbCl}_{3}(g) \\
& 3 \mathrm{Sb}_{3} \mathrm{O}_{4} \mathrm{Cl}(\mathrm{s}) \rightarrow 4 \mathrm{Sb}_{2} \mathrm{O}_{3}(s)+\mathrm{SbCl}_{3}(g) \\
& \text { s = solid; g = gaseous }
\end{aligned}
$$

Eq. (1) was extended for the better representation of the reaction. However, when the antimony trioxide is added to PVC it becomes very effective to flame retarding, because it acts as a synergist for the halogen contained inherently in the
PVC (56.7\%). This situation is similar to that obtained from the stimulation of halogen flame retardants and the same compounds will be formed when ATO reacts with chlorine released from the PVC after it is burned [13-16].

\section{Materials and methods}

a. Materials: PVC S-5070 (Ongrovil ${ }^{\circ}$ ) from BorsodChem Zrt., Hungary; Dioctyl Phthalate (DOP) as plasticizer; Newstab 50 as stabilizer; Wax-E as lubricant; and antimony trioxide (ATO) with chemical formula $\mathrm{Sb}_{2} \mathrm{O}_{3}$.

b. Sample preparation: four batches were prepared with a laboratory extruder (Göttfert Extrusiometer G20) at $170{ }^{\circ} \mathrm{C}$. The barrel diameter is $20 \mathrm{~mm}$, the length $20 \mathrm{D}$, i.e. $400 \mathrm{~mm}$. A screw of comparison rate was used with long comparison zone (PVC screw). The die was $10 \times 4$ $\mathrm{mm}$ flat die suitable for extruding rods for L. O. I. test without further forming.

c. Thermal tests: Limiting oxygen index test (L. O. I.) was done by the instrument Stanton Redcroft FTA flammability unit with oxygen and nitrogen cylinders gas and accurate pressure control system found in BorsodChem Zrt. The results obtained from this test shown in Fig. 1. As expected, we can observed from this figure that the limiting oxygen index of PVC increased with ATO additions, This increase is direct, as the percentage of ATO increased the value of L. O. I. will increase. Also, the percentage of oxygen which the PVC samples needs to burn will increase. This behavior due to the ATO absorbed heat and there will be phase transformations in its internal structure. This represent endothermic process which decreased surface temperature which will prevent fire propagation $[4,13]$. 


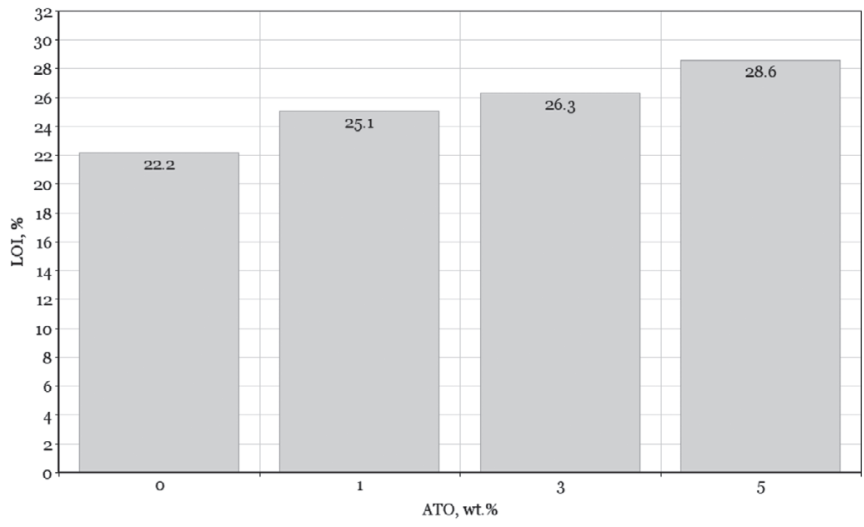

Fig. 1. Limiting oxygen index of plasticised PVC vs. ATO additives 1. ábra ATO tartalmú lágyított PVC oxigén indexe

d. Scanning electron microscopy FESEM: FESEM was used for the structural analysis of plasticised PVC. This test was done by using Carl Zeiss EVO MA10 SEM.

e. Thermal gradient: thermal imaging camera (FLIR Systems) was used in order to determine the thermal gradient in L. O. I. test samples as shown in Fig. 2. The Emissivity was 0.5 , reflected apparent temperature $20^{\circ} \mathrm{C}$, and Object distance $1.0 \mathrm{~m}$

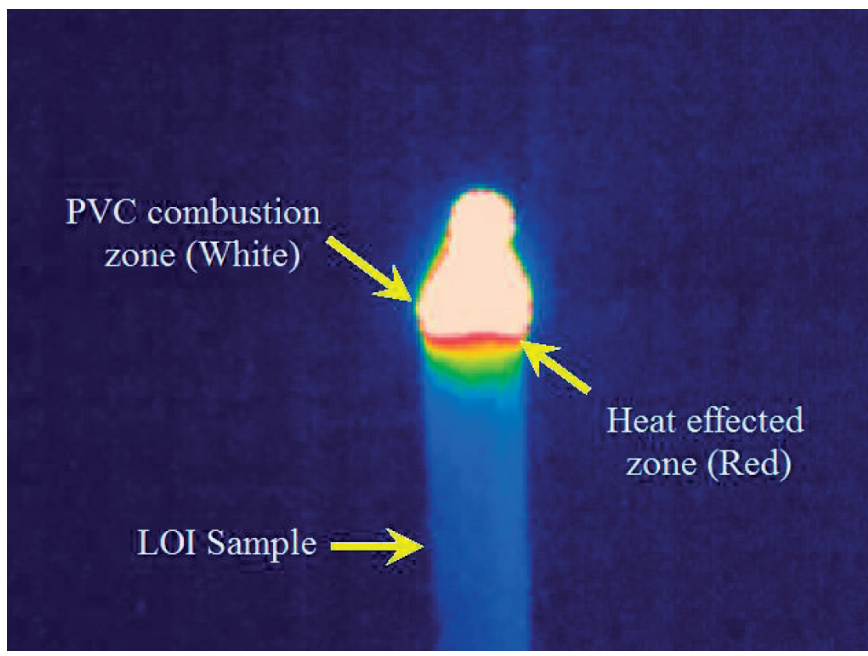

Fig. 2. FLIR thermal gradient image for heat affected zone (HAZ) in plasticised PVC L. O. I. test

2. ábra A höhatásnak kitett zóna (HAZ) FLIR termikus gradiens képe a lágyitott PVC L. O. I. vizsgálata közben

\section{Results and discussion}

The images obtained from SEM show that the chlorine percentage decreased associated with an increase in carbon percentage after L. O. I. test, when comparing with PVC SEM images before the test, as shown in Fig. 3 and Fig. 4. This state as a result of PVC dehydrochlorination, where it begins to release chlorine in form of $\mathrm{HCl}$ from its internal structure at high temperatures, i.e. begins to decompsion in these tempreature. The loss of chlorine from the internal structure of PVC involves not only burnt and directly exposed layers of fire, but also extends to the under layers far from the combustion zone, which we called heat affected zone (HAZ) as shown in figures.
In addition, we noticed that the under layers of the test samples ignite faster when cutting the burned area and continue the L. O. I. test, which means the low flammable resistance for heat affected layer because less chlorine. However, this situation soon changes and PVC resistance to ignition improves after the addition of the antimony trioxide as shown in Figs. 5-7, where the released chlorine will be reduced from the heat affected zone. It is true that the antimony trioxide alone is not a flame retardant but it improves and increases flame retardation if it is added to halogen-containing flame retardant material containing chlorine. Antimony trioxide and chlorine combine compounds that have the ability to inhibit flame and improve flame resistance. While the structure of PVC contains a chlorine, it begins to release as a result of combustion and thermal decomposition. This chlorine reacts with the antimony trioxide forming $\mathrm{SbCl}_{3}$ compound [17], which help to reduce PVC combustion and increase heat resistance of the heat affected zone. After the addition of antimony trioxide, the heat affected layer ignites relatively slowly when the burnt area is cut and the L. O. I. test continues, which means high flame resistance of this layer. The efficient flame retardant is the $\mathrm{SbCl}_{3}$ is already prepared in the heat affected zone, therefore the extinguishing of the falme starts sooner.

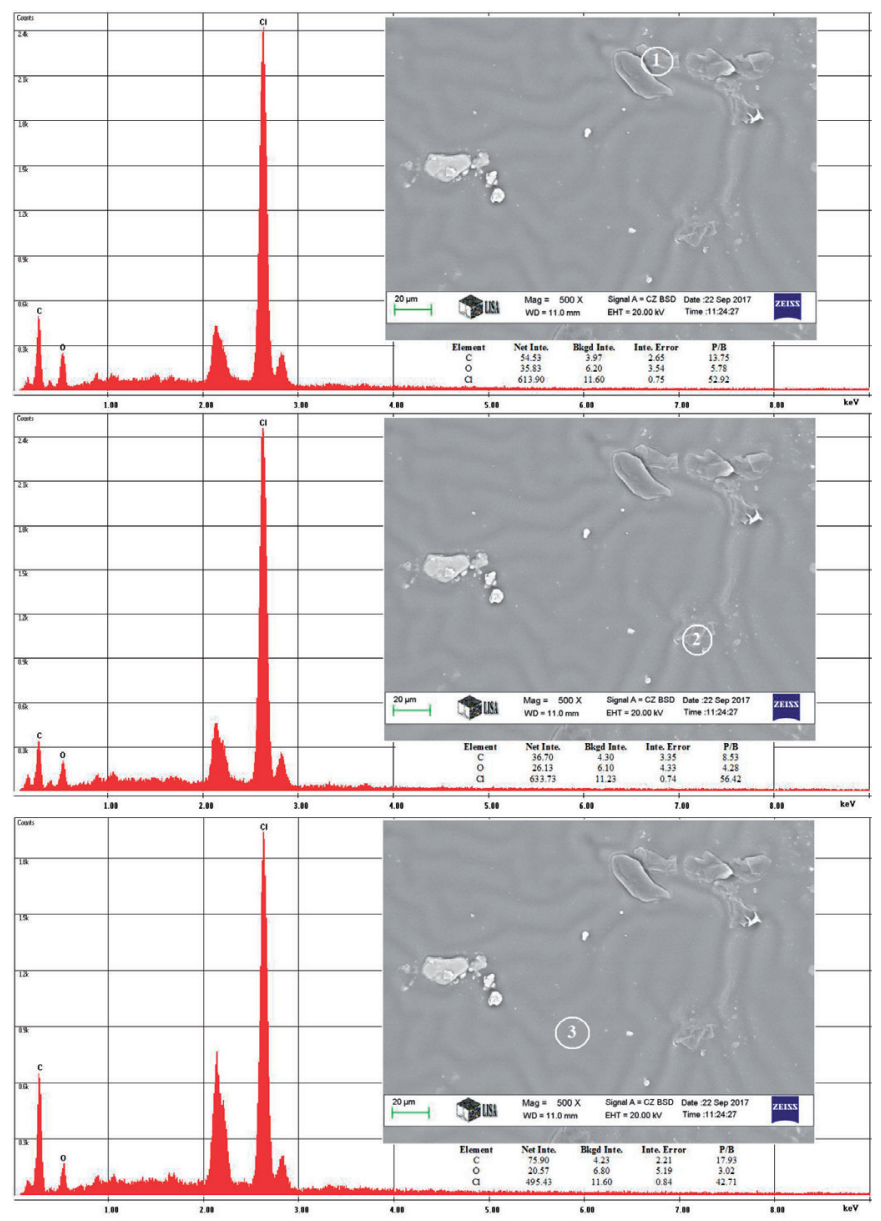

Fig. 3. SEM - energy dispersive X-ray microanalysis for unburned plasticised PVC 3. ábra SEM - energia diszperzív röntgen mikroanalízis az el nem égett PVC-ben 

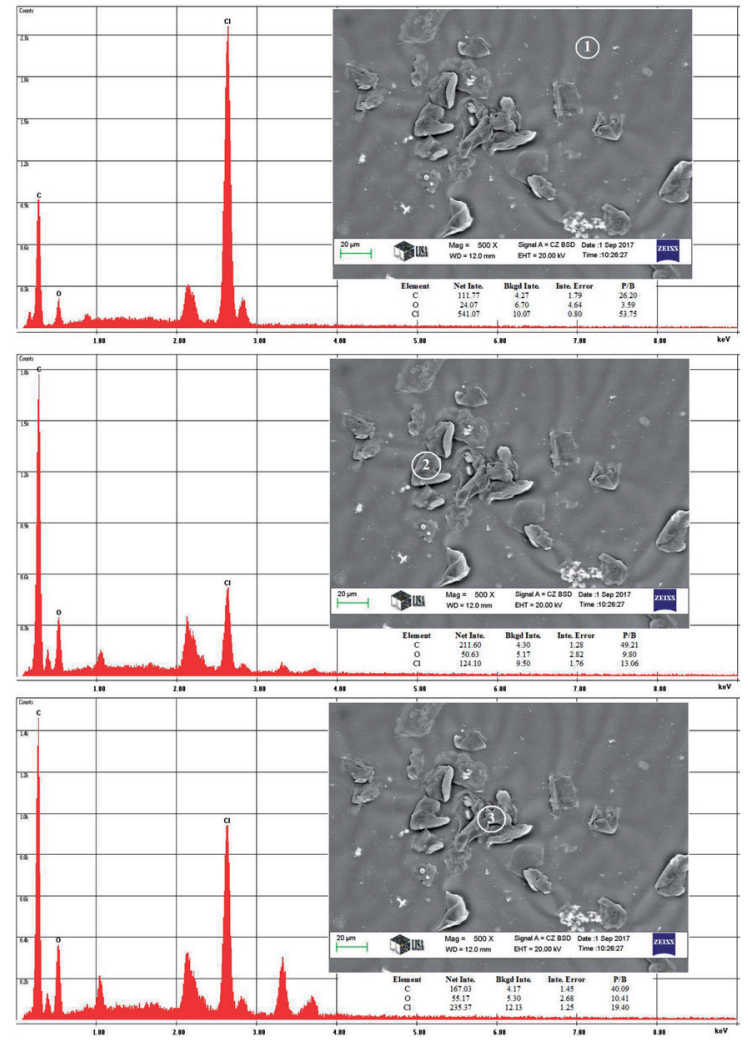

Fig. 4. SEM - energy dispersive X-ray microanalysis for HAZ in burned plasticised PVC L. O. I. sample

4. ábra SEM - energia diszperzív röntgen mikroanalizis HAZ esetében az elégett lágyított PVC L. O. I. mintában
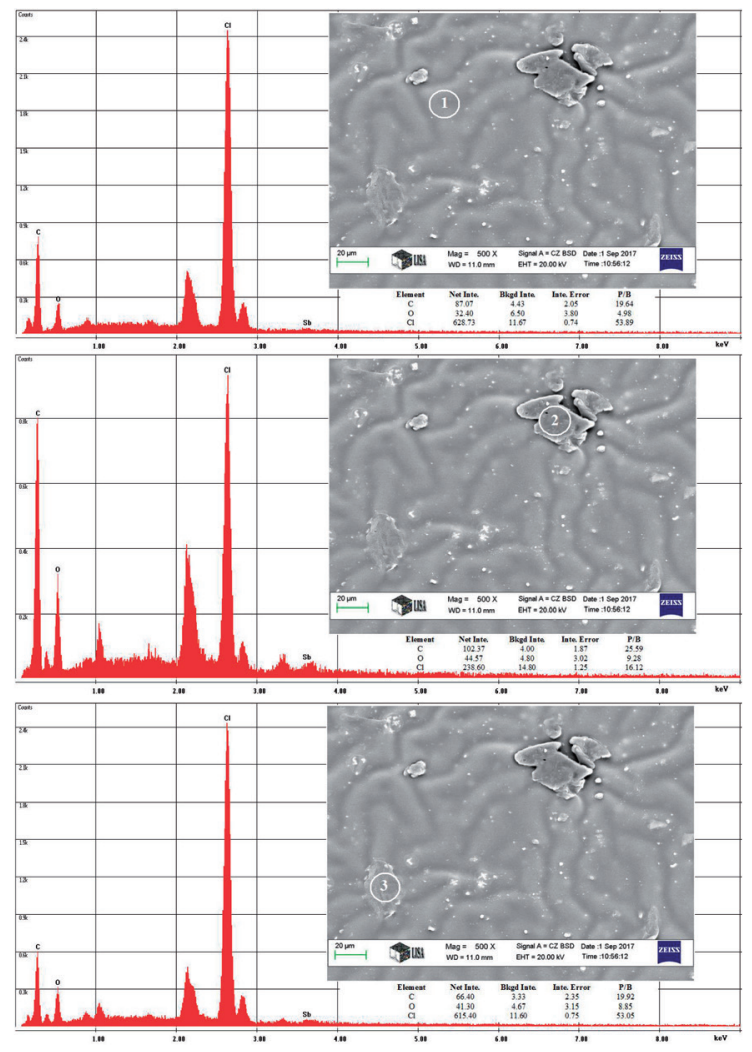

Fig. 5. SEM - energy dispersive X-ray microanalysis for HAZ in burned plasticised $\mathrm{PVC}+1 \% \mathrm{Sb}_{2} \mathrm{O}_{3}$ LOI sample

5. ábra SEM - energia diszperzív röntgen mikroanalizis a $H A Z$ az elégetett lágyított PVC-ben. $\mathrm{Sb}_{2} \mathrm{O}_{3}$ tartalom $1 \%$
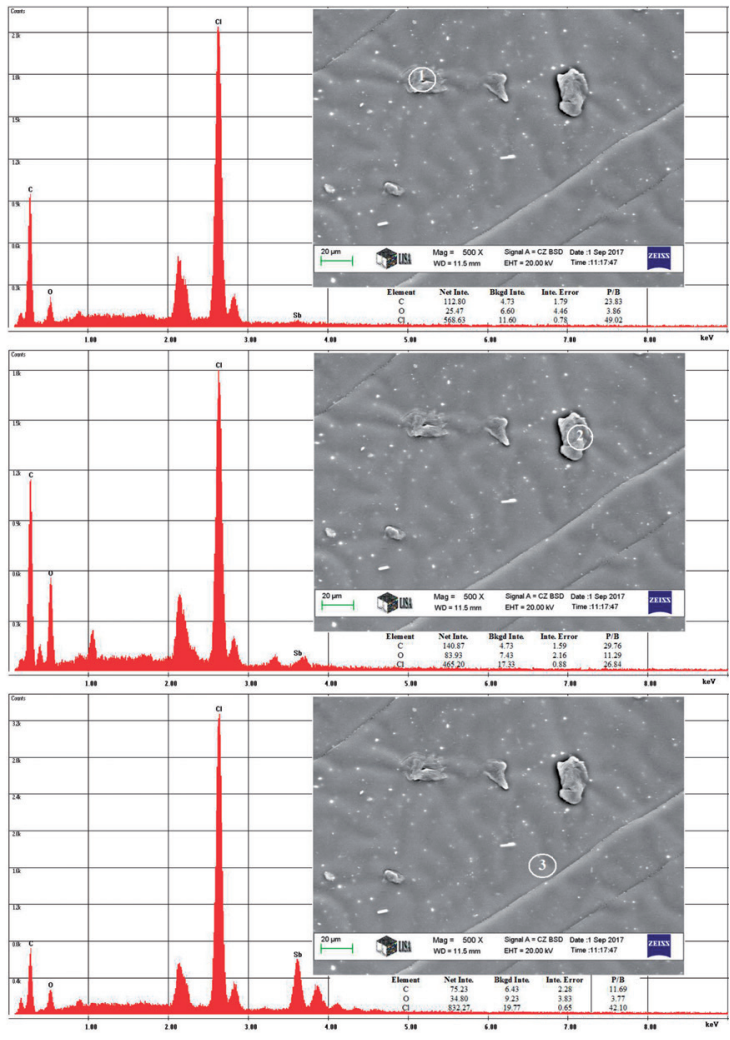

Fig. 6. SEM - energy dispersive X-ray microanalysis for HAZ in burned plasticised $\mathrm{PVC}+3 \% \mathrm{Sb}_{2} \mathrm{O}_{3}$ LOI sample

6. ábra SEM - energia diszperzív röntgen mikroanalízis a HAZ az elégetett lágyított PVC-ben. $\mathrm{Sb}_{2} \mathrm{O}_{3}$ tartalom $3 \%$
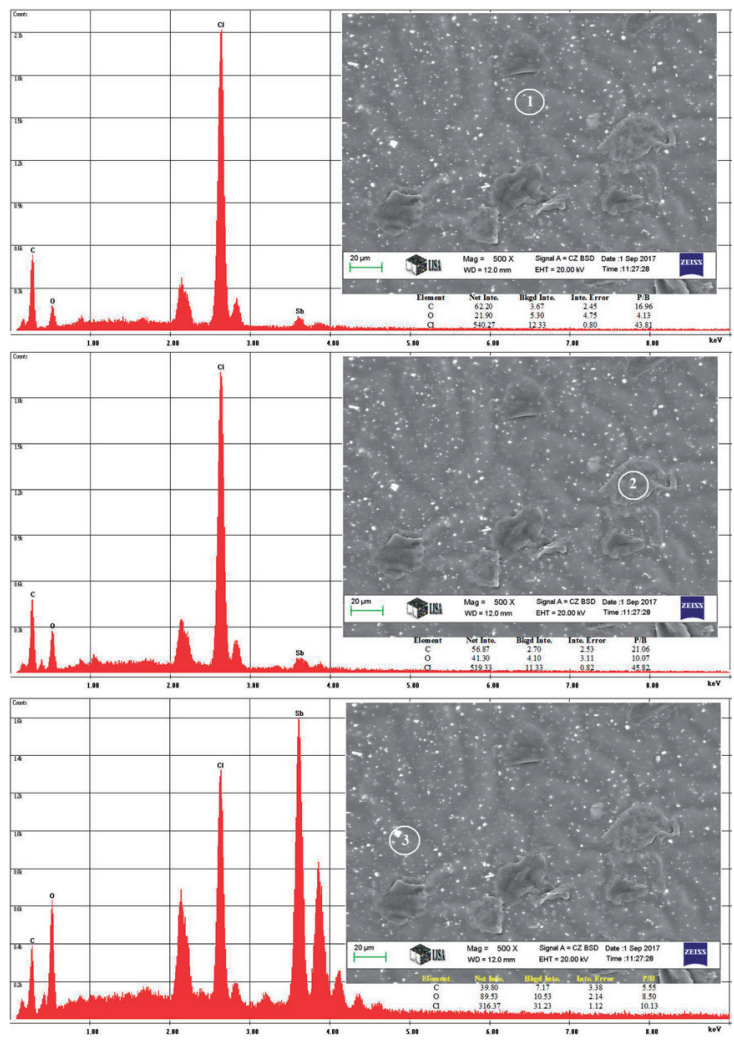

Fig. 7. SEM - energy dispersive X-ray microanalysis for HAZ in burned plasticised $\mathrm{PVC}+5 \% \mathrm{Sb} \mathrm{O}_{3}$ LOI sample

7. ábra SEM - energia diszperzív röntgen mikroanalizis a HAZ az elégetett lágyított PVC-ben. $\mathrm{Sb}_{2} \mathrm{O}_{3}$ tartalom 5\% 


\section{Conclusions}

The PVC combustion is not confined to the flame exposed layer but extends beyond the burning layer. Experiments have shown a decrease in chlorine content in the non burning heat affected zone. Without $\mathrm{Sb}_{2} \mathrm{O}_{3}$ ease of ignition of heat affected zone was observed due to structural changes. The heat affected zone has a low inclination of ignition and is immediately flame retardant if the compound contains $\mathrm{Sb}_{2} \mathrm{O}_{3}$ because the $\mathrm{SbCl}_{3}$ is already present in this layer.

\section{Acknowledgements}

After completing our research, we would like to thank Csaba Kónya and Gabriella Szemere at the BorsodChem company as well as Árpád Kovach at the laboratory of scanning electron microscopy, University of Miskolc, who helped us to complete this research.

\section{References}

[1] Al-Mosawi, A. I. (2016): Flammability of composites, Chapter 14, in Njuguna, J. (ed.) Lightweight composite structures in transport: Design, manufacturing, analysis and performance. UK: , pp.361-369. ISBN: 9781-78242-325-6 (print), ISBN: 978-1-78242-343-0 (online). DOI: https://doi.org/10.1016/B978-1-78242-325-6.00014-1

[2] Al-Mosawi, A. I. (2003): Study using of antimony trioxide material as a flame retardant material, M.Sc. thesis, Babylon University, Iraq .

[3] Al-Maamori, M. H. - Al-Mosawi, A. I. (2014): Increasing resistance of polymeric composite materials to elevated temperatures by coating with antimony tetroxide material, Central Organization for Standardization and Quality Control (COSQC), No.3743, International Classification (C08C19/30), Iraqi Classification (4).

[4] Horrocks, A. R. - Price, D. (eds.) (2008): Advances in Fire Retardant Materials, $1^{\text {st }}$ edn., CRC Press, October 7. ISBN: 9781420079616.

[5] Morgan, J. H. (ed.), (2016): SFPE Handbook of Fire Protection Engineering, 5th edition, Springer, ISBN 978-1-4939-2564-3, 978-1-49392565-0 (eBook).

[6] Al-Mosawi, A. I. (2012): Flame Retardancy of Polymers, LAP LAMBERT Academic Publishing, ISBN: 25531 -659 -3-978.

[7] Morley, J. C. - Grossman, R. F. (2008): Flame Retardants and Smoke
Suppressants, in Grossman, R.F., (Ed.), Handbook of Vinyl Formulating, 2nd edition, John Wiley and Sons, New York, N.Y. , pp. 403-414, ISBN 9780-471-71046-2, https://doi.org/10.1002/9780470253595.ch16

[8] Le Bras, M. G. - Camino, Bourbigot, S. - Delobel, R. (eds.) (1998): Fire Retardancy of Polymers - The Use of Intumescence, The Royal Society of Chemistry.

[9] Technical information (2013): Flame retardant mechanism of antimony trioxide, Nihon Seiko Co., Ltd., Japan.

[10] Coaker, A.W. (2003): Fire and Flame Retardants for PVC, Journal of Vinyl \&Additive Technology, vol. 9, no. 3, pp. 108-115. https://doi.org/10.1002/vnl.10072

[11] Al-Mosawi, A.I . - Ahmed, J. K. - Hussain, H. A. (2012): Evaluation flame retardancy of epoxy composite by using design of experiments, in OPTIROB 2012, Applied Mechanics and Materials, vol.186, pp 156-160. https://doi.org/10.4028/www.scientific.net/AMM.186.156

[12] Rodolfo, Jr. A. - Innocentini-Mei, L. H. (2017): Smoke suppression of PVC and copper (II), molybdenum and zinc oxides mixtures: TG/MS and TG/FTIR studies, in Proc.PVC 2017, p. 25-27.

[13] The Vinyl Institute, (1996): Fire and polyvinyl chloride - Vinyl in Design, A Division of The Society of the Plastics Industry, Inc.65 Madison Avenue, Morristown, New Jersey.

[14] Al-Mosawi, A. I. - Marossy, K. (2017): Performance Evaluation of Mixing Mechanism and its Effects on Thermal Behaviour of Plasticised PVC, International Journal of Engineering and Technology (IJET), Vol.9, No.6, pp.4389-4396. https://doi.org/10.21817/ijet/2017/v9i6/170906130

[15] Marcelo H. (2017): Fire properties of polyvinyl chloride, The Vinyl Institute, Washington, DC, USA.

[16] Babrauskas, V. - Harris, R. H. - Gann, R. G. - Levin, B. C. - Lee, B. T. Peacock, R. D. - Paabo, M. - Twilley, W. - Yoklavich, M. F. - Clark, H. M. (1988): Fire Hazard Comparison of Fire Retarded and Non-Fire-Retarded Products, NBS Special Publication 749.

[17] Sheng, G. Z. - Si-yuan, M. - WANG, H. (2007): Inorganic Flame Retardant and Smoke Suppressant in Flexible PVC, Journal of Hengshui University, Vol.9, No.1, pp. 93-96.

\section{$\underline{\text { Ref.: }}$}

Al-Mosawi, Ali I.- Marossy, Kálmán: Heat effected zone in unburned, antimony trioxide containing plasticised $P V C$ Építőanyag - Journal of Silicate Based and Composite Materials, Vol. 70, No. 3 (2018), 86-89. p. https://doi.org/10.14382/epitoanyag-jsbcm.2018.16

\section{INTERNATIONAL COMPOSITES CONGRESS}

For the fourth time the International Composites Congress (ICC) takes place as the opening event of COMPOSITES EUROPE. Focussing on the topic "Composites - On the Path to Becoming a Key Industry?", international experts discussed current topics which could be further enhanced during the subsequent tour of COMPOSITES EUROPE.

Lectures on the following themes will be presented at the $4^{\text {th }}$ ICC:

- Efficient processes / Integrative production - Pultrusion technology / Additive Manufacturing

- Multimaterial-solutions

- Responsible care (sustainability, recycling)

- Market developments

- Standardisation

- SMC/BMC

- Hybrid Thermoplasti Molding

- Cooperations (industry-research, industry-industry) 